\title{
Pelatihan penggunaan mesin sablon botol untuk pelaku UMKM makanan minuman ringan di Kota Pasuruan
}

eISSN 2721-415X, ISSN 2721-4168 ejournal.umm.ac.id/index.php/altruis 2021, Vol 2(4):94-97

DOI:10.22219/altruis.v2i4.18123

(C)The Author(s) 2021

(c) (i) 4.0 International license

\author{
Lestari Setyowati ${ }^{1}$, Sari Kamina ${ }^{1}$, Arif Sutrisno ${ }^{1}$, Fariza Wahyu Arizal ${ }^{1}$, Barotun Mabaroh ${ }^{2}$
}

\begin{abstract}
One way to attract consumers to buy products is through attractive packaging. Therefore, this community service (SSI) aims to provide training related to packaging polishing using screen printing for small scale industry actors in the city of Pasuruan. Specifically, the purpose of writing this article is to describe the implementation and results of bottle screen printing training as a form of community service for food and beverage business actors in the city of Pasuruan. The method implemented is divided into three main stages, namely analysis as well as preparation, implementation, and evaluation. The team collaborated with the Demer sablon company, Pasuruan city to provide screen printing training materials. In the training session, many participants were enthusiastic about asking questions and greatly appreciated the training activities. Also, in the practice of screen printing, many participants produced good screen prints in the first trial $(84 \%)$, while others (16\%) produced ordinary screen prints. It can be concluded that community service activities through bottle screen printing training for SSI actors in the city of Pasuruan are very useful and increase the knowledge and basic skills of participants on how to screen print packaging bottles manually.
\end{abstract}

\section{Keywords}

Training, screen print, small scale industries

\section{Pendahuluan}

Kebanyakan usaha industri rumah tangga (IRT) saat ini berusaha bertahan di tengah pandemi COVID 19. Hal itu mendorong mereka untuk berinovasi menciptakan produk olahan, baik itu olahan minuman ataupun makanan. Di beberapa daerah, terjadi penurunan usaha produksi industri rumah tangga. Ada usaha yang gulung tikar, namun ada juga yang bertahan dan berkembang.

Fitri \& Bundo (2021) misalnya, melalui penelitiannya melaporkan bahwa terdapat penurunan penghasilan industri rumah tangga di Kota besar seperti Padang. Mereka yang dapat bertahan di dalam badai pandemi COVID 19, bisanya mengubah strategi pemasaran dari luring ke daring, yaitu melalui grup WhatsApp, Facebook, dan semacamnya (Fitri \& Bundo, 2021). Bagi mereka yang bertahan, pelaku usaha melakukan banyak cara untuk menarik minat konsumen, salah satunya adalah dengan memperbaiki kemasan produk yang dimiliki. Berdasarkan penelitian yang dilakukan oleh Resmi \& Wismiarsi (2015), kemasan mempengaruhi minat konsumen secara signifikan untuk membeli produk tertentu.

Plastik kemasan adalah salah satu bentuk promosi yang termurah (Wulandari et al., 2013). Hal ini dikarenakan plastik ringan dan mudah dibawa kemanamana. Di kemasan plastik tersebut dapat di tempel/disablon nama/logo toko. Secara umum, berdasarkan pengamatan, produk minuman IRT dikemas di wadah tanpa identitas yang unik. Padahal pelaku usaha industri rumah tangga minuman/makanan olahan dapat mengemas produk lebih baik lagi.

Beberapa pelaku UMKM di kota Pasuruan tidak memiliki kemasan produk yang representatif. Sebagai contohnya produk olahan susu milik M99 Beverage. Pada awalnya, produk olahan susu M99 beverage hanya ditempeli oleh stiker sederhana yang dibuat di Ms.Word (Setyowati et al., 2019). Namun, kemasan produk menjadi lebih baik setelah menjadi mitra pengabdian pada masyarakat dari salah satu PT di kota Pasuruan.

Contoh yang selanjutnya berdasar pengamatan yaitu produk makanan "Jeng Sri" yang berada di Kota Pasuruan. "Jeng Sri" bergerak di bidang olahan makanan (bumbu pecel) dan minuman (kolak, es buah, jamu), yang mana kemasannya hanya berupa cup plastik dan ditempel dengan stiker word sederhana. Produk IRT lainnya yaitu minuman jamu "Mbak Nunuk" yang dipasarkan di kota Pasuruan. Produk minuman ini juga hanya dimasukkan dalam botol

\footnotetext{
${ }^{1}$ Fakultas Sastra, Universitas Negeri Malang ${ }^{2}$ Fakultas Pedagogi dan Psikologi, Universitas PGRI Wiranegara

Korespondensi:

Setyowati, Fakultas Sastra, Universitas Negeri Malang

Email: lestari.setyowati.fs@um.ac.id, sari.karmina.fs@um.ac.id, arif.sutrisno.fs@um.ac.id, fariza.wahyu.arizal.fs@um.ac.id,
} 
kemasan biasa dengan nama sederhana. Melihat beberapa contoh diatas, maka sablon botol untuk kemasan makanan menjadi perlu. Selain untuk memberi identitas produk, sablon/screen printing dapat juga menjadi media murah untuk promosi produk tersebut (Tobroni, 2011).

Teknik cetak saring/screen printing biasa disebut sablon. Sablon biasanya diaplikasikan pada kain (Supatmo, 2015). Namun dalam perkembangannya, screen printing tidak hanya diaplikasikan pada kain saja, namun juga pada media yang lain yaitu botol (bottle screen printing) dengan proses penyablonan yang sama seperti kain (Christavent, 2019).

Berdasarkan paparan di atas, maka tim pengabdi menawarkan solusi berupa pelatihan sablon botol untuk kemasan minuman. Pelatihan sablon botol ini dirasa perlu karena tidak banyak usaha IRT yang bergerak di bidang minuman olahan yang mampu menyablon kemasannya secara mandiri. Oleh karena itu, pengabdian ini bertujuan untuk memberi pelatihan pada pelaku UMKM di kota Pasuruan. Secara spesifik tujuan penulisan artikel ini adalah untuk (1) mendeskripsikan pelaksanaan pelatihan sablon botol sebagai bentuk pengabdian pada masayarakat pada pelaku makanan dan minuman di kota Pasuruan, dan (2) mendeskripsikan pendapat peserta pelatihan dan hasil dari pelaksanaan pelatihan sablon botol pada pelaku UMKM di kota Pasuruan.

\section{Metode}

Metode yang dilaksanakan pada pelatihan ini menyesuaikan dengan kebutuhan mitra. Secara garis besar metode yang dilaksanakan dibagi menjadi tiga tahapan utama, yaitu analisis, persiapan, pelaksanaan, dan evaluasi. Pada tahap awal, tim mengidentifikasi masalah mitra. Langkah selanjutnya adalah mempersiapkan kegiatan. Kegiatan tersebut dilanjutkan dengan melaksanakan kegiatan pelatihan sablon botol untuk peserta UMKM mamin di kota Pasuruan, dan langkah terakhir adalah melakukan evaluasi dan umpan balik. Evaluasi ini tidak hanya berasal dari tim tapi juga dari berasal dari peserta yang mengikuti pelatihan.

Sasaran pelatihan ini adalah pelaku usaha makanan dan minuan di kota Pasuruan. Pada awal persiapan, tim berencana mengundang 50 pelaku UMKM yang ada di kota Pasuruan, baik yang tergabung dalam Disperindag kota Pasuruan, maupun yang tidak. Namun dikarenakan adanya Pemberlakuan Pembatasan Kegiatan Masyarakat (PPKM) untuk pencegahan penularan COVID 19, maka tim pengabdi hanya mengundang 25 orang pelaku usaha UMKM. Undangan disebarkan melalui Gogle form, dan apabila respon telah mencapai 25 orang maka google form tersebut ditutup. Pelaksanaan kegiatan pelatihan Sablon botol ini dilaksanakan di Aula Gedung serbaguna Universitas PGRI Wiranegara, Pasuruan, pada tanggal 28 Juli 2021 dengan menerapkan protokol kesehatan. Protokol kesehatan yang dilakukan adalah memakai

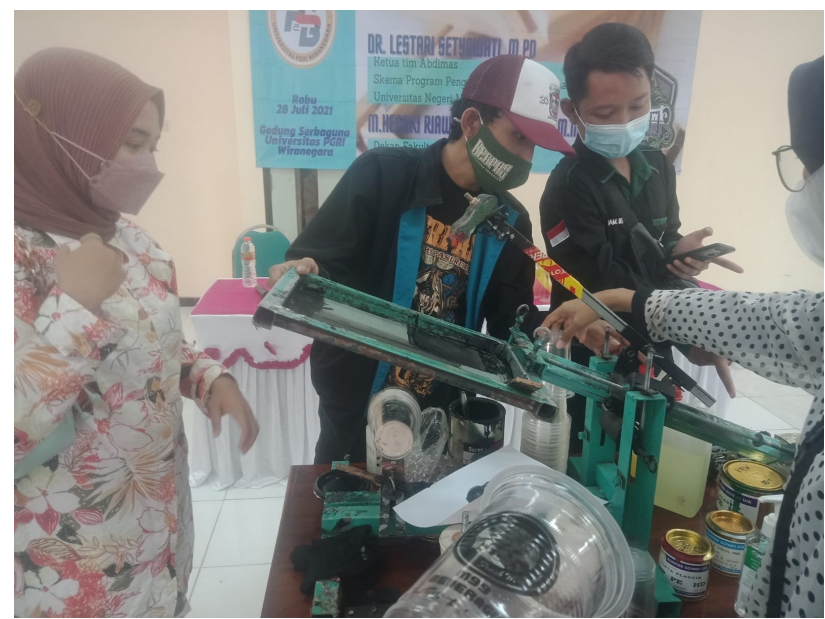

Gambar 1. Peragaan Alat Sablon

masker, tempat duduk peserta berjarak 1 meter, dan disiapkan handsanitizer di dalam ruangan.

\section{Hasil dan Diskusi}

Pelatihan ini dilaksanakan di kota Pasuruan. Tim Bersama mitra menggunakan Gedung serbaguna lantai 2 Universitas PGRI Wiranegara, yang beralamatkan di jalan Ki Hajar Dewantara 27-29 kota Pasuruan. Terdapat 25 peserta yang mengikuti pelatihan sablon botol ini. Sebagai pemateri sablon botol, tim bekerja sama dengan Demer sablon, sebuah perusahaan produksi kemasan berbasis di kota Pasuruan. Lebih lengkapnya, Demer Sablon berada di Jl. Patiunus, Bugul Kidul, Kota Pasuruan. Demer Sablon telah banyak berkiprah dalam pemberian pelatihanpelatihan sablon botol di kota Pasuruan dan sekitarnya. Pelatihan sablon ini dibagi menjadi beberapa bagian, yaitu pengenalan mesin sablon dan peralatannya, demo cara menggunakannya, dan praktik penggunaan mesin sablon oleh peserta.

Mesin sablon botol yang digunakan adalah mesin sablon yang dimiliki oleh Demer Sabon sendiri yang dibawa lengkap dengan semua peralatannya. Peralatan yang dibutuhkan yaitu tinta sablon, film, molding. Tim menyediakan botol plastik untuk praktek menyablon. Materi pelatihan disampaikan secara lisan oleh Demer Sablon berdasarkan pengalaman. Materi pelatihan tidak hanya berfokus pada teori saja, namun juga praktik atau demonstrasi bagaimana menyablon yang baik dan apa yang harus dilakukan sebelum menyablon. Peserta pelatihan ditunjukkan berbagai ukuran cetakan/molding. Keputusan untuk menggunakan molding yang mana, tergantung dari ukuran botol plastik yang akan digunakan. Adapun tahapan proses penyablonan botol sama untuk semua jenis ukuran molding.

Pada saat pelaksanaan pelatihan, terdapat antusiasme yang tinggi dari peserta pelatihan. Banyak diantara mereka yang merasa tertarik dengan sablon botol ini. Beberapa diantara mereka mengajukan pertanyaan seputar sablon 
botol. Beberapa pertanyaan yang diajukan adalah (1) dimana mendapatkan mesin sablon botol; (2) bagaimana membuat screen/film untuk sablon botol; (3) apakah sablon hanya berlaku untuk botol saja ataukah juga berlaku untuk kemasan kotak; dan (4) bagaimana menyablon yang baik untuk menghasilkan hasil yang maksimal.

Penyaji dari Demer sablon mengatakan bahwa mesin sablon botol dapat dipesan di toko-toko/pengrajin yang secara khusus memang membuat mesin sablon botol. Untuk mesin sablon botol sederhana, Demer sablon dapat membuat mesin yang dikehendaki. Sedangkan untuk membuat screen/film sablon botol harus dimulai dengan disain logo yang dikehendaki. Pembuatan screen adalah tahapan terpisah dari penyablonan. Pendek kata, sebelum menyablon, maka screen harus tersedia terlebih dahulu.

Untuk memudahkan, Demer sablon menyediakan jasa disain dan pembuatan screen sablon. Sablon ternyata juga tidak hanya berlaku untuk botol saja. Penyaji mengatakan bahwa kotak makanan juga bisa disablon, namun tentu saja alat sablon berbeda dengan alat sablon botol. Untuk menyablon yang baik diperlukan keterampilan yang terasah. Penyaji mengungkapkan bahwa menyablon adalah suatu keterampilan kasar yang harus diasah. Jadi, wajar bila penyablonan pertama tidak menjamin hasil langsung menjadi baik. Untuk mendapatkan hasil sablon yang maksimal, setidaknya dibutuhkan waktu latihan yang hampir setiap hari agar sablon tampak halus dan bagus.

Untuk memeriahkan pelatihan, panitia menyediakan doorprize bagi peserta yang aktif bertanya dan mampu menggunakan mesin sablon botol dengan baik. Doorprize adalah salah satu hal yang menarik peserta. Disamping terkait sablon botol, banyak pula peserta yang bertanya mengenai cara menyablon botol, dan bagaimana industri rumah tangga / UMKM dapat bekerja sama dengan perguruan tinggi untuk meningkatkan kualitas dan kuantitas produk dan pemasarannya.

Di akhir pelatihan tim dan peserta berfoto bersama untuk dokumentasi kegiatan. Banyak dari peserta yang mengharapkan kegiatan ini berlangsung secara berkelanjutan.

\section{Persepsi , Keaktifan, dan Skill Peserta Pasca Pelatihan Sablon}

Pelatihan ini mendapatkan respon yang positif dari peserta. Beberapa di antara mereka mengungkapkan bahwa pelatihan ini sangat bermanfaat bagi mereka.

"Pelatihan ini sangat keren. Kami mencoba mesin nya, dan ternyata menggunakan mesin sablon itu membutuhkan keterampilan tersendiri,' (Peserta/Br)

"Kami ingin menggunakan mesin sablon untuk meningkatkan nilai jual produk kami. Pelatihan ini sangat bermanfaat," (Peserta/Sr)

"Kami ingin membeli mesin sablon. Kami ingin menyablon produk kami secara mandiri.." (Peserta/Tr)
Dari pendapat di atas, dapat diketahui bahwa peserta sangat mengapresiasi kegiatan ini. Beberapa di antara mereka bahkan memberi pertanyaan mendetail mengenai alat-alat yang dibutuhkan dan dimana mendapatkannya. Berdasarkan hasil pengamatan, tim mendapati bahwa peserta cukup aktif dalam bertanya dan seluruh peserta mendapat kesempatan yang sama untuk melakukan uji coba menyablon botol.

Berdasar observasi diketahui terdapat tujuh pertanyaan dari peserta. Tiga pertanyaan pada sesi satu, dan empat pertanyaan pada sesi dua. Hasil observasi juga menunjukkan bahwa semua peserta aktif mencoba penggunaan mesin sablon botol. Pelatihan sablon botol ini tidak hanya menarik minat peserta, namun juga tamu undangan. Terdapat delapan orang tamu undangan yang turut mencoba menggunakan mesin sablon untuk menyablon botol plastik yang telah disediakan. Hasil sablon para tamu undangan tidak kalah bagusnya dengan peserta pelatihan.

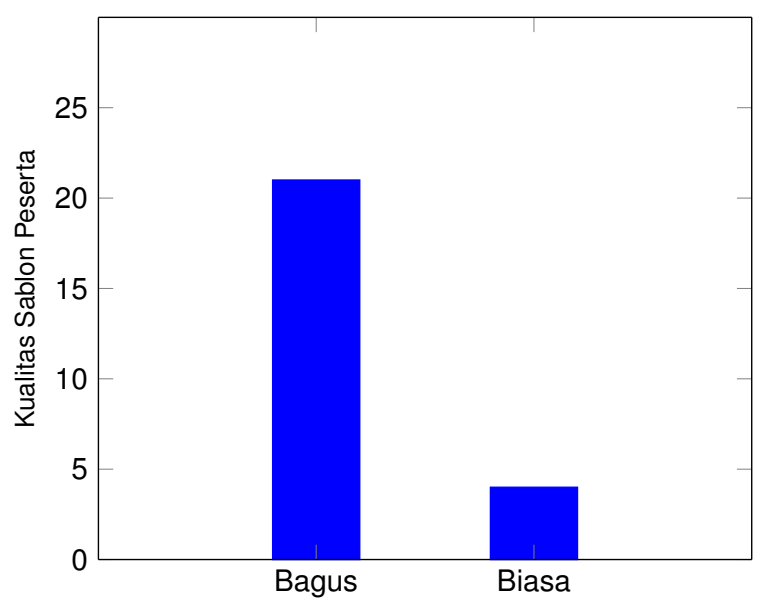

Gambar 2. Kualitas Percobaan sablon peserta

Pada kegiatan berlatih menyablon, banyak peserta menghasilkan hasil sablon yang bagus pada cobaan pertama (21 orang), sedangkan 4 orang lainnya menghasilkan hasil uji coba sablon yang biasa. Hasil sablon yang bagus ditandai dengan melekatnya tinta sablon dengan baik di atas botol, tidak berserakan, dan terlihat rata. Sedangkan kualitas sablon yang biasa ditandai dengan tidak meratanya tinta hasil sablon. Misalnya, pada satu sisi tulisan/gambar hasil sablon film tebal, tapi pada sisi lainnya tidak. Atau dengan kata lain, hasil sablon tidak merata. Namun, hal ini bisa dipahami karena saat pelatihan adalah masa pertama peserta mencoba menyablon botol dengan mesin sablon. Bila disimpulkan secara umum, semua peserta dapat menggunakan mesin sablon botol pada saat pelatihan meski dengan hasil yang beragam.

\section{Kesimpulan}

Kegiatan pelatihan sablon botol yang dilaksanakan dapat disimpulkan cukup berhasil. Hal ini dapat dilihat dari respon peserta dan keaktifan peserta selama kegiatan 
berlangsung. Peserta merasa kegiatan ini bermanfaat dan meningkatkan pengetahuan dan keterampilan dasar mereka terkait bagaimana menyablon botol kemasan secara manual.

Beberapa saran disampaikan pada beberapa pihak terkait. Pertama, perguruan tinggi (PT) dan UMKM harus bersinergi untuk meningkatkan kerjasama yang saling menguntungkan. Di tingkat PT, kegiatan pengabdian pada masyarakat bekerjasama dengan UMKM dapat membantu dosen untuk merealisasikan salah satu Tri Dharma PT yaitu pengabdian masyarakat. Sedangkan bagi UMKM, kegiatan pelatihan yang dilakukan oleh PT, dapat membantu meningkatkan kualitas dan kuantitas produksi produk yang dibuat, dan mungkin juga pemasarannya.

Kedua, setiap kegiatan pelatihan kewirausahaan, seperti sablon botol, harus dilaksanakan secara berkelanjutan. Memiliki keterampilan dasar dalam menyablon belumlah cukup. Menyablon membutuhkan keterampilan yang harus diasah terus menerus. Oleh karena itu, tim abdimas PT dapat bekerjasama dengan UMKM/ mitra untuk melaksanakan kegiatan serupa dalam bentuk workshop yang berkelanjutan. Dan ketiga, kegiatan pelatihan kewirausahaan seyogyanya tidak hanya melibatkan UMKM dan PT namun juga Disperindag setempat. Hal ini akan meningkatkan kualitas kegiatan pelatihan, dan dapat mengenalkan produk peserta pelatihan pada level yang lebih luas.

\section{Ucapan Terimakasih}

Kegiatan Pengabdian masyarakat dalam skema program pengembangan kewirausahaan: mahasiswa dan masyarakat ini dibiayai oleh PNBP Universitas Negeri Malang untuk pendanaan tahun 2021

\section{Referensi}

Christavent, C. (2019). Bottle Screen Printing, Cetak Visual di Permukaan Botol. Diakses pada 18 September 2021 dari https://melipirkepinggiran.home.blog/2019/08/22/bottlescreen-printing-cetak-visual-di-permukaan-botol/

Fitri, R., \& Bundo, M. (2021). Dampak Covid-19 Terhadap Industri Rumah Tangga Pangan di Kota Padang. Jesya (Jurnal Ekonomi Dan Ekonomi Syariah), 4(2), 784-792. https://doi.org/https://doi.org/10.36778/jesya.v4i2.379

Resmi, N. \& Wismiarsi, T. (2015). Pengaruh Kemasan Dan Harga Pada Keputusan Pembelian Minuman Isotonik. Jurnal Manajemen dan Bisnis Sriwijaya, 13(1), 1-20

Supatmo. (2015). Screen Printing Dalam Industri Grafika Pada Era Digital. Imaginasi: Jurnal Seni. 9(2), 105-116.

Setyowati, L., Badriyah, Ahsana, A. (2019). Meningkatkan Usaha Industri Rumah Tangga Olahan Susu Segar Aneka Rasa Di Kecamatan Purworejo Kota Pasuruan Melalui Program Kemitraan Masyarakat Stimulus. Vokasindo, 7(2), 66-87.

Tobroni , M.I. (2011) Teknik Sablon Sebagai Media Apresiasi Karya Desain Pada Tshirt. Jurnal Humaniora, 02(01), diakses pada 18 September 2021 dari http://eprints.binus.ac. id/13827/

Wulandari, A., Waluyo, S., \& Novita, D. D. (2013). Prediksi umur simpan kerupuk kemplang dalam kemasan plastik polipropilen beberapa ketebalan. Jurnal teknik pertanian lampung, 2(2), 105-114. 